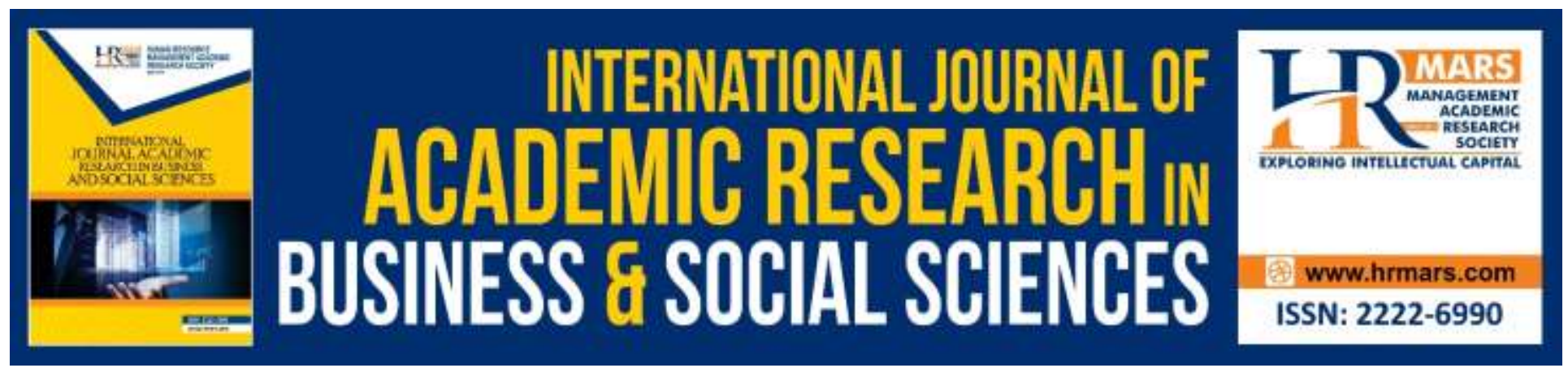

\title{
Bequest as an Instrument in Wealth Planning in Islamic Law
}

\author{
Rashida Amira Binti Rashid, Wan Khairul Aiman Wan Mokhtar, Asma Afifah \\ Rashid Eusoff Amiruddin, Ahmad Safwan Jamaludin
}

To Link this Article: http://dx.doi.org/10.6007/IJARBSS/v9-i11/6574

DOI: 10.6007/IJARBSS/v9-i11/6574

Received: 08 October 2019, Revised: 28 October 2019, Accepted: 04 November 2019

Published Online: 27 November 2019

In-Text Citation: (Rashid, Mokhtar, Amiruddin \& Jamaludin, 2019)

To Cite this Article: Rashid, R. A. B., Mokhtar, W. K. A. W., Amiruddin, A. A. R. E., Jamaludin, A. S. (2019). Bequest as an Instrument in Wealth Planning in Islamic Law. International Journal of Academic Research in Business and Social Sciences, 9(11), 550-556.

Copyright: (c) 2019 The Author(s)

Published by Human Resource Management Academic Research Society (www.hrmars.com)

This article is published under the Creative Commons Attribution (CC BY 4.0) license. Anyone may reproduce, distribute, translate and create derivative works of this article (for both commercial and non-commercial purposes), subject to full attribution to the original publication and authors. The full terms of this license may be seen

at: http://creativecommons.org/licences/by/4.0/legalcode

Vol. 9, No. 11, 2019, Pg. 550 - 556

http://hrmars.com/index.php/pages/detail/IJARBSS

JOURNAL HOMEPAGE

Full Terms \& Conditions of access and use can be found at http://hrmars.com/index.php/pages/detail/publication-ethics 


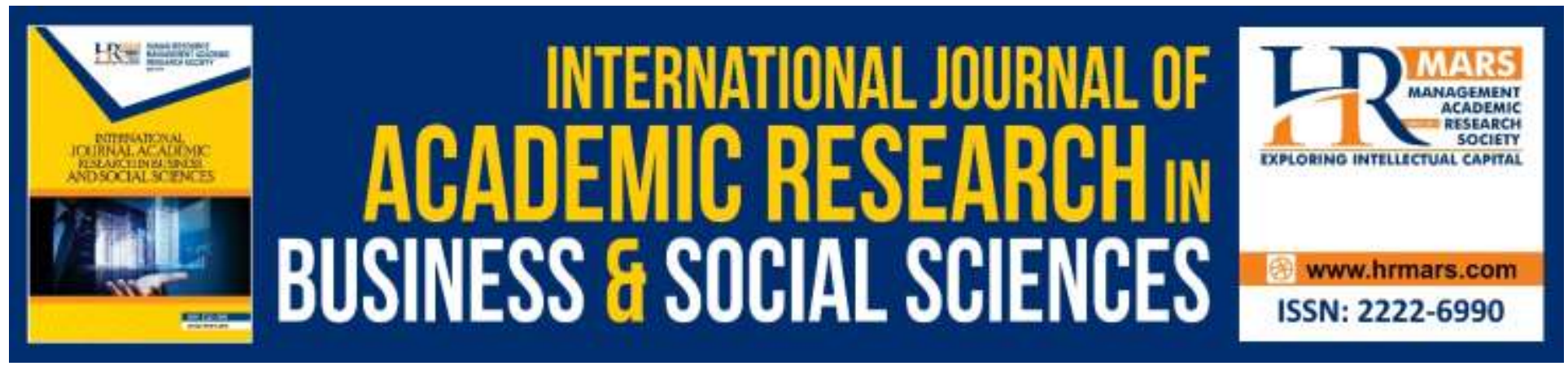

\title{
Bequest as an Instrument in Wealth Planning in Islamic Law
}

\author{
Rashida Amira Binti Rashid, Wan Khairul Aiman Wan Mokhtar, \\ Asma Afifah Rashid \\ Eusoff Amiruddin, Ahmad Safwan Jamaludin \\ Universiti Sultan Zainal Abidin (UniSZA), Gong Badak Campus, 21300, Kuala Nerus, Terengganu, \\ Malaysia
}

\begin{abstract}
The bequest of Islamic law is a concept that is contrast to civil law. There are not many people in our country that are competent in this profession. Lack of exposure about the bequest and will to the community is one of the reasons why our people tend to have less knowledge about wealth property planning. There are a lot of issues that arise in this topic which is bequest. A lot of people just like to stick to their own mindset such as everyone can receive the will no matter who you are. These people just love to believe in the myths instead of looking up more about this issue. Therefore, the purpose of this article is to focus on these two issues which is to explain more about which people that do not have the right to get bequest and to elaborate more about the reasons or situations on why bequest can be cancelled. So, by doing the research for this article, there are several methods that will be used in this writing. For the qualitative study, library method had been used in this writing. A lot of data and documents that have been collected by doing this method. There are several journal and document that helps to ease the research and solve the problems that are arising in our country. Bequest is appropriate as an instrument for wealth management. Nevertheless, to put up this instrument, revisions proposed in this article are compulsory to the existing law.

Keywords: Bequest, Wealth Planning, Instrument, Qualitative Research, Managing and Planning Property
\end{abstract}

\section{Introduction}

Managing and planning property is highly encouraged in Islam. In some cases, estate management is no longer an option but is a requirement and compulsory especially when there is a condition where the execution of a matter is mandatory, we perform. In this context, Islam allows us to dispose of property or grant benefits to certain people through wills or bequest. 
However, the implementation of this instrument is subject to Islamic law and shall not arbitrarily used, let alone it may invite confusion and disputes among the closest family members. Therefore, this article will explain about the law the estate administration will be in Malaysia generally, and for the implementation of his or her special wills.

\section{Research Methodology}

A good research was depended from its methodology. The right methodology will produce the right findings. Therefore, the importance of applied research methodology in a study is to make a research organized and comprehensive (Mokhtar, 2017; Tehrani \& Razali, 2018).

Qualitative research had been used in order to achieve the objectives of this research. Hence, method of library research was used. The data was collected and obtained from books, articles and journals. From the collected data, the data were analyzed through the contain anlaysis. Form the analysed data, the conclusion were been made (Mokhtar, 2017).

\section{Findings and Research Discussion}

In the way of deliberating about the bequest, there are three categories that will be discuss in this research. First is the definitions of bequest (wasiyyah). Second is the law of wasiyyah. Third is the reasons or situations on why bequest can be cancelled and the people who do not have the right to get property.

\section{Definition of Bequest (will)}

The word of bequest or will is coming from Arabic word, wasa which means to make promise. Its also means to deliver or give something (Ibn-Manzur, 2003). Meanwhile the word wasiyyah (wills) is a plural noun of wasa, which refers to something that is advised but then is used to show the act or behavior of the will (Mustafa, n.d.).

Bequest also defined as will from the testator of the goodness that will be carry out after the testator's death. In the other words, bequest is a property given by the owner (testator) to others (the legatee) after the testator passes away or defined as to make property to others (legatee) (Al-Zuhaili, 1998). Bequest is the confession that any person made during his lifetime on his own property and benefits that can be used for the welfare or any purpose permitted by the Islamic Law after his death. The assets of the Muslims' deceased that do not have any bequest will be distribute to the heirs or relatives according to Faraid method, which is from Islamic Law. Bequest (wasiyyah) is a deal that will come after the death of the testator. The will is implemented the total of memorial expenses and any unsettled debts.

\section{Law of Wasiyyah}

1. Wajib (compulsory)

Bequest law is compulsory if there is responsibility which must be implemented to Allah the Almighty and mankind that must be carried out. If he has the obligations that need to be fulfilled such as hajj or zakat but he thinks that he cannot fulfill the responsibility. And he thinks that he needs someone who can carry out it for him, so he is compulsory to 
write the will for someone to fulfill it for him as well as if he has any property entrusted or an outstanding debt (Shahid, 2014; Armaou \& Antoniou, 2018).

2. Mustahab (recommended but not essential)

In Islam, bequest is really recommended (but not essential) in order to approach to Allah, the Almighty. One of the ways is to write the will (wasiyyah) to give some of our properties to the one who in need, the one who lives in poverty especially to our relatives that not receive the share from the heritage property. Besides, we also can share our properties through the wasiyyah to other muslims who are in need, or to the community such as to build an educational institution, social health and etc (Al-zuhaili, 1998).

3. Haram (Forbidden)

Bequest will be forbidden according to shariah' law if the testator writes a will on giving the things that are forbidden in Islam such as bequeath alcohol or bequeath things that can ruin or harm the moral of the other people (testate). This kind of bequest cannot be implemented. The testator could not bequest something that can burden the testate and avoid them from getting the shares that had been divided by shariah' law. Allah strictly prohibited the bequest that can harm other people (Shahid, 2014; Akomeah, Bentil, Musah, 2018).

4. Harus (Mubah)

Bequest will be mubah if the bequest is for friends or the rich people that are neither intelligent nor believers that always do good. And if the purpose of the bequest is aiming for good things and wants to strengthen the relationship between the other people, this bequest will be sunnah as it shows respect and obey to Allah, the Almighty.

5. Makruh

The will is makruh when the testator is someone that poor and have the relatives or friends that not wealthy as well and always in need for help. The bequest also makruh when the testator gives the will to someone that is bad or hypocrite as they will use the benefit of the will for something that are leads to crime or something that harmful.

\section{How and When Is the Cancellation of Bequest}

The wasiyyah would be cancelled in the following conditions: First is when the testator withdrew his bequest during his life time. It is when the testator expresses that he or she wants to cancel the bequest either through spoken or written. As long as the testator said the cancellation clearly or allegorically, the will or the wasiyyah will be automatically cancelled. Next is if the testator became not sane after writing his wasiyyah and continued on this illness up to when he passed away. In addition, when the testator had used, lose, consumed the property that he or she wants to give as will and thereby invalidates the bequest.

When the property is going through damages or ruin, the will or bequest will be automatically decline. Besides, the wasiyyah will be cancelled too when the testate passed away before the testator and the wasiyyah is fix only for the testate. Last but not least, when the testate is passing 
away before the testator, so the bequest will be received by the heirs of the testate if only the testate is passing before receiving the will (Al-Khin, n.d).

\section{People Who Do Not Have Rights to Receives Bequest}

As we already know, there are some pillar that the testator and testate need to fulfill before they can give or receive the property or benefits of their wealth. In contrary, there are some people that do not have the rights to have or get the bequest for some reasons.

1. Servant

Servant is a man who has no authority for himself because he is owned, can be sold, may be granted and inherited. He is dominated and absolutely has no power at all. That is why the servant has no right to inherit because Allah distributes the inheritance to the person who has the authority to do something but the slave has zero authority even for himself. "And whoever that buys a slave and, in the meantime, the slave owns a property, then his property belongs to the seller, unless the buyer makes a condition" (Hadith History of Bukhari and Muslim).

And Umar al-Khatab said that if the slave does not have the right to own, he is not entitled to inherit any property because if he inherits, he needs to transfer his property to his owner.

2. Al-Qatil (Murderer)

If a person is entitled to receive the bequest (testate), but the person kills the person who will write the bequest (testator), for example, a child who is impatient and could not wait to inherit the legacy of his father, so he kills his father. So, the child is not entitled and did not have the rights to take the inheritance of his father.

"The murderer of the testator could not inherit the property or the heirs" (Hadith History of Tirmizi and Hadis History of Ibnu Majah).

3. Different Religion or Apostasy

For the other religion if their relatives died when they were in Jews, while the heirs were Muslims, then the heirs of the Muslim cannot inherit his property or bequest and vice versa.

Syaikh Muhammad bin Shalih Al-Utsaimin said: "They did not get the inheritance because between both of them, they were separated through syar'i. Therefore, Allah said to the prophet Nuh 'Alahis Salam explaining that his son who disbelieved by his word."

Furthermore, Syaikh explained: There are two things where the other religion can inherit the property of the other religion. First: Al-Wala. That is the man who frees the slave, he earns the legacy of the liberated boy, despite other religions. Second: The disbelieving relatives then converted to Islam before divestment.

4. Talak Raj'i that had finished Iddah period

The woman who has finished her iddah period, will did not get the heritage from her husband who had died. Similarly, otherwise. But if any of them died before the expiration of the iddah period, they will inherit the properties of their spouse.

5. Triple Thalaq 
The woman who is divorced three times is called thalaq ba'in. When a husband divorces her in a healthy state, then dies, then the wife does not get her inheritance. Similarly, otherwise. Or the husband is in a state of illness and there is no suspicion of divorcing him because he fears the wife takes her inheritance, so the wife has no inheritance. But if the husband divorces it because it means that the wife does not get the inheritance, then the wife will get the inheritance (Al-Tuwaijiri, 2014).

6. Foster-child

In this case it also includes foster parents. Both of them have no inheritance if one of them died, even as his religion and recognized as his own son, or his own father, had a birth certificate and was recorded as a child or a biological father, since the term parents and children were one blood caused by marriage according to syar'ii. Allah said;

"If one dies, and he has no child and has a sister"

(QS An-Nisa: 176)

7. Step father or step mother

Step children will not get any inheritance from will or bequest even when their step mother or step father is passing away.

8. Child from Li'an

When a husband accuses his wife of committing adultery and swears in the name of Allah four times, that the accusation is true, and the fifth oath is accompanied by the words "God's curse upon me when I lie", then his wife also took his oath as mentioned in the letter An-Nur verse 6, then his son is recognized as li'an (not recognized by the husband), then the child does not get any inheritance when the deceased died. Similarly, if the child dies. The reason is, because the child is not recognized by the strangers. The child does not get the inheritance from his mother and vice versa.

9. Illegitimate Child

The child who is born from the adultery, then the child does not get the inheritance of the men who are committing adultery as well, and vice versa. However, the child gets heritage from her mother and vice versa. The reason is, because the child who gets the inheritance is a child or a blood, born with syar'i marriage.

\section{Conclusion}

From the discussion above we can conclude that the will is an instrument that can be used in property planning and management. However, it is also clear that the will does not give us the power to determine who will inherit the estate after our death. This is because after the death of a person, the distribution of the property is subject to Faraid Law. In any case, our plans are certainly subject to obey to Allah, the Almighty. As a human, we cannot determine who among the experts our heirs are more beneficial to us because everything will happen in time front is under the provision of Allah s.w.t. Planning a property management is strongly encouraged in Islam but there are legal limits to the law that we must obey in ensuring that we do not violate the rights of beneficiaries who have been ensured under the law of inheritance of Islamic property. 


\section{Acknowledgement}

This paper is founded on the research project of the Fundamental Research Grant Scheme FRGS/1/2018/SSI03/UNISZA/02/2 (Project No: RR279). Special appreciation is owed to Ministry of Higher Education Malaysia (MOHE) and Universiti Sultan Zainal Abidin (UniSZA) for sponsoring and supporting this research.

\section{Corresponding Author}

Wan Khairul Aiman bin Wan Mokhtar (Ph.D), Senior Lecturer, Universiti Sultan Zainal Abidin (UniSZA), Gong Badak Campus, 21300 Kuala Nerus.

Email: wk_aiman@yahoo.com / wkhairulaiman@unisza.edu.my

\section{References}

Armaou, M., \& Antoniou, A.-S. (2018). Secondary School Teachers' Perceptions of Job Resources in Learning Organizations. Multilingual Academic Journal of Education and Social Sciences, 6(1), 4-20.

Akomeah, E., Bentil, P., Musah, A. (2018). The Impact of Capital Structure Decisions on Firm Performance: The Case of Listed Non-Financial Institutions in Ghana, International Journal of Academic Research in Accounting, Finance and Management Sciences 8 (4): 1-15.

Latif, A. R. A. (1986). Wasiat dalam Islam: Definisi dan Tarafnya di Malaysia. Bangi: Universiti Kebangsaan Malaysia.

Al-Zuhayli, W. (1998). al Wasaya wa al Waqf fi al Fiqh al Islami. Damshiq: Dar al Fikr.

Al-Zuhayli, W. (2001). al Fiqhul Islami Wa al-adillatih. Damascus: Dar al Fikr.

Ibrahim, A. (1976). The Distribution of Estates According to Shafi'i Law. Singapura: Malaysian Law Journal. Cara-cara Pengurusan Wasiat Umat Islam (Negeri Selangor). (No. 13/2008).

Hamdi, K. (1987). al Mawarith wa al Hibah wa al Wasiyyah. Iskandariyah: Dar al Matbu'ah wa al Jami'iyyah.

Al-Tuwaijiri, A. (2014). Mukhtaskhar Al Fiqhul Islami' (n.p.).Tashillul Faraid. 21-22.

Mokhtar, W. K. A. W. (2017). Concept Al-Hadīth Al-Mawḍū'iy as a Method of Collecting and Analyzing Research's Data. International Journal of Academic Research in Business and Social Sciences, 7(2), 2222-6990.

Tehrani, H. T., \& Razali, A. B. (2018). Developing Thinking Skills in Teaching English as a Second/Foreign Language at Primary School. International Journal of Academic Research in Progressive Education and Development, 7(4), 13-29 